\title{
ANALYSIS OF THEMATIC LEARNING IN THE 2013 CURRICULUM SDN 7 KEBUMEN
}

\author{
Teguh Rahayu, Kurnia Wardani Putri, Isnaeniatun Umifaiqoh, Kartika Chrysti \\ Suryandari
}

Universias Sebelas Maret

rahayuteguh99@gmail.com

\section{Article History}

accepted 30/09/2018

approved 12/10/2018

published 30/10/2018

\section{Keywords}

2013 curriculum,

implementation, thematic

learning.

\begin{abstract}
The policy of applying the 2013 curriculum has an impact on the implementation of thematic learning. This study aims to describe the application of thematic learning in SDN 7 Kebumen. This study uses descriptive qualitative methods. The subjects of this study were teacher of class I and teacher of class IV, 5 studens of class I and 5 students of class IV. The students were taken from students with high, medium and low abilities. Data collection techniques are carried out through observation, interviews, and questionnaires. Data analysis techniques used are source triangulation and technical triangulation The results of this study prove that the application of thematic learning has been running in accordance with the 2013 curriculum, teachers and students respond well to the application of thematic learning. But there are still a few obstacles. Among them are apperception and motivation are less memorable for students. Thus, it can be concluded that the implementation of thematic learning class I and IV in SDN 7 Kebumen is in accordance with the 2013 curriculum, but there needs to be an increase in apperception and motivation.
\end{abstract}

Social, Humanities, and Education Studies (SHEs): Conference Series https://jurnal.uns.ac.id/shes

p-ISSN 2620-9284 e-ISSN 2620-9292 


\section{PENDAHULUAN}

Pendidikan merupakan pilar utama dalam pembangunan bangsa. Sependapat dengan Janawi (2012:15) yang menyatakan bahwa sejarah telah membuktikan bahwa kemajuan dan kejayaan suatu bangsa di dunia sangat ditentukan oleh pembangunan di bidang pendidikan. Mulyasa (2015:13) mengemukakan bahwa mutu pendidikan di Indonesia khususnya mutu output pendidikan masih terbilang rendah jika dibandingkan dengan mutu output pendidikan di negara lain, baik di kawasan ASEAN maupun di Asia. Hal ini dibuktikan dengan laporan pembangunan manusia UNDP (Badan Program Pembangunan PBB) tahun 2010, Indonesia berada pada rangking $108 \mathrm{HDI}$ (Human Development Index) dari 182 negara. Laporan tersebut menunjukkan bahwa Indonesia belum mampu menghadapi persoalan mendasar dalam dunia pendidikan. Oleh sebab itu, mutu pendidikan di Indonesia membutuhkan penanganan serius karena pendidikan memegang peranan yang sangat penting bagi bangsa dan negara.

Sebagai bentuk keseriusan pemerintah dalam menangani mutu pendidikan dengan selalu mengembangkan kurikulum di Indonesia, yakni kurikulum 2013. Akbar, dkk (2016:2) menyatakan bahwa sejak tahun 2013 pemerintah telah mengeluarkan kebijakan tentang penerapan kurikulum baru atau yang dikenal dengan kurikulum 2013. Kurikulum 2013 lahir dengan semangat untuk memberbaiki pendidikan Indonesia agar mampu menjadi wadah bagi anak-anak Indonesia untuk mengembangkan segala potensi mereka. Secara implikatif kebijakan tersebut berdampak pada diterapkannya pembelajaran tematik di jenjang sekolah dasar, sekolah menengah pertama, dan sekolah menengah atas. Depdiknas (Akbar, dkk, 2016:2) mengemukakan bahwa pembelajaran tematik merupakan model dari kurikulum terpadu yang memakai tema untuk mengaitkan beberapa mata pelajaran sehingga dapat memberikan pengalaman bermakna untuk peserta didik. Pembelajaran tematik menurut Majid (Akbar, dkk, 2016:2) adalah pendekatan pembelajaran yang mengaitkan berbagai bidang studi yang mencerminkan dunia nyata di sekeliling siswa dan dalam rentang kemampuan, serta perkembangan anak. Dari pendapat kedua ahli, dapat disimpulkan bahwa pembelajaran tematik adalah model dari kurikulum terpadu yang mengaitkan berbagai bidang studi dengan kehidupan nyata disekeliling siswa yang dikemas dalam bentuk tema, sehingga dapat memberikan pengalaman bermakna bagi peserta didik.

Irwandi (2012:192) menyatakan bahwa dalam pelaksanaan pembelajaran tematik ada tahapan yang harus dilaksanakan dalam proses pembeajaran, diantaranya kegiatan pendahuluan/awal/pembukaan, kegiatan inti yang mencakup kegiatan eksplorasi dan konfirmasi, kegiatan penutup/akhir dan tindak lanjut dan dilanjutkan dengan penilaian pembelajaran tematik.

Akbar, dkk (2016:19) menyatakan bawa karakteristik pembelajaran tematik yang perlu dipahami, yaitu: (a) student centered atau berpusat pada siswa, guru hanya berperan sebagai fasilitator dan motivator. (b) memberikan pengalaman langsung, siswa dihadapkan dengan hal/masalah yang nyata dan terjadi disekitar siswa sebagai dasar untuk memahami hal-hal yang lebih bersifat abstrak. (c) pemisahan mata pelajaran tidak begitu jelas, focus pembelajaran diarahkan pada tema yang dikaitkan dengan kehidupan peserta didik. (d) menyajikan konsep dari berbagai muatan, konsep dari berbagai mata pelajaran dipadukan dengan tema yang ada untuk membentuk pengetahuan peserta didik secara holistik. (e) bersifat fleksible, mengaitkan antar mata pelajaran berdasarkan isi, kehidupan dan lingkungan sekitar peserta didik. menggunakan prinsip belajar sambil bermain dan menyenangkan melalui metode yang dapat mengaktifkan peserta didik dalam kegiatan pembelajaran.

Permendikbud Nomor 67 Tahun 2013 tentang Kerangka Dasar dan Struktur Kurikulum SD/MI menyebutkan bahwa pelaksanaan kurikulum 2013 pada SD/MI dilaksanakan melalui pembelajaran tematik-terpadu dari kelas I sampai kelas VI (Kurniasih, I dan Berlin, S., 2016:4). Berdasarkan survei diketahui bahwa SDN 7 Kebumen sudah melaksanakan kurikulum 2013 dimulai pada tahun ajaran 2016/2017 
di kelas I dan IV, beberapa guru sudah mengikuti diklat sebelum melaksanakan pembelajaran tematik, serta memfasilititasi guru dan siswa berupa buku pembelajaran. Namun dalam pelaksanaannya masih belum maksimal karena mendapatkan beberapa hambatan. Untuk itu peneliti melakukan penelitian untuk mengetahui: (a) pelaksanaan pembelajaran tematik di SDN 7 Kebumen tahun ajaran 2018/2019 di kelas I dan IV; (b) tanggapan guru terhadap pembelajaran tematik; dan (c) tanggapan siswa kelas I dan IV dalam menerima pembelajaran tematik.

\section{METODE}

Penelitian ini merupakan penelitian kualitatif deskriptif. Sugiyono (2017:8) menyatakan bahwa pada penelitian kualitatif, peneliti bertindak sebagai human instrument. Sebagai instrument, peneliti harus memiliki bekal teori dan wawasan yang luas. Untuk mendapatkan pemahaman yang luas dan mendalam, maka teknik pengumpulan data yang digunakan bersifat triangulasi, yaitu menggunakan berbagai teknik pengumpulan data secara bersamaan. Analisis datanya bersifat induktif berdasarkan fakta-fakta yang ditemukan di lapangan, kemudian disusun menjadi hipotesis atau teori. Metode kualitatif digunakan untuk mendapatkan data yang mendalam, suatu data yang mengandung makna. Makna adalah data yang sebenarnya. Oleh karenya dalam penelitian kualitatif tidak menekankan pada generalisasi, tetapi lebih menekankan pada makna.

Sugiyono $(2017,215)$ menyatakan bahwa pada penelitian kualitatif, populasi diartikan sebagai wilayah generalisasi yang terdiri dari obyek/subyek yang mempunyai kualitas dan karakteristik tertentu yang dapat ditetapkan oleh peneliti untuk dipelajari dan kemudian ditarik kesimpulannya. Sedangkan sampel adalah sebagian dari populasi itu. Dalam penelitian ini, subjek penelitian adalah guru dan siswa kelas I dan kelas IV Sekolah Dasar Negeri 7 Kebumen. Dengan jumlah siswa kelas I sebanyak 20 siswa yang tediri dari 11 siswa perempuan dan 9 siswa laki-laki. Jumlah siswa kelas IV 35 siswa yang terdiri dari 15 siswa perempuan dan 20 siswa laki-laki. Data penelitian ini diambil menggunakan triangulasi teknik dan triangulasi sumber. Teknik yang digunakan dalam penelitian ini meliputi: a) observasi terhadap pembelajaran tematik kelas I dan IV; b) wawancara terhadap guru kelas I dan IV; dan c) angket terhadap siswa kelas I dan IV. Langkah-langkah analisis data dalam penelitian ini adalah sebagai berikut: 1) Data Reduction (Data Reduksi), 2) Data Display (Penyajian Data), dan 3) Conclusion Drawing (Verivication).

\section{HASIL DAN PEMBAHASAN}

Untuk memperoleh data tentang pembelajaran tematik di SDN 7 Kebumen, maka peneliti melakukan: (1) observasi pelaksanaan pembelajaran di kelas I dan IV,menggunakan angket yang memiliki alternative jawaban sangat baik/baik/cukup/kurang. (2) obervasi mengenai tanggapan siswa terhadap pembelajaran tematik, di kelas I dan IV menggunaka angket yang memiliki alternative jawaban sangat setuju/setuju/netral/kurang setuju/sangat tidak setuju. (3) wawancara kepada guru untuk mengetahui tanggapan guru terhadap pembelajaran tematik di kelas I dan IV, jenis wawancara yang digunakan adalah wawancara terbuka. Kebumen:

Hasil observasi pelaksanaan pembelajaran tematik di kelas I dan IV SDN 7 
Tabel 01. Rata-rata persentase setiap aspek

\begin{tabular}{llllll}
\hline No & \multicolumn{1}{c}{ Aspek } & $\begin{array}{c}\text { Sangat } \\
\text { baik }\end{array}$ & \multicolumn{1}{c}{ Baik } & Cukup & Kurang \\
\hline 1. & Kegiatan awal & $0 \%$ & $33.33 \%$ & $66.67 \%$ & $0 \%$ \\
2. & Kegiatan inti & $57.14 \%$ & $30.95 \%$ & $11.9 \%$ & $0 \%$ \\
3. & Kegiatan akhir & $75 \%$ & $0 \%$ & $25 \%$ & $0 \%$ \\
\hline
\end{tabular}

Berdasarkan tabel di atas dapat diketahui bahwa pada aspek kegiatan awal, sudah berjalan cukup baik, dengan persentase sebesar $66.67 \%$. Pada aspek kegiatan inti, sudah berjalan sangat baik, dengan persentase $57.14 \%$. Kemudian pada aspek kegiatan akhir juga sudah berjalan sangat baik, dengan persentase $75 \%$. Hasil penelitian di atas menunjukkan bahwa pelaksanaan pembelajaran tematik sudah baik. Hal ini sesuai dengan pendapat Irwandi (2012:192) yang menyatakan bahwa pelaksanaan pembelajaran tematik melalui 3 tahapan, yaitu kegiatan awal, kegiatan inti, dan kegiatan akhir.

Angket yang disebar pada kelas I dan IV bertujuan untuk mengetahui ketertarikan, kesenangan, dan keaktifan siswa terhadap pembelajaran tematik. Hasil yang diperoleh dari angket tersebut, yaitu $29.17 \%$ siswa sangat setuju, $29.17 \%$ siswa setuju, $5.42 \%$ siswa netral, $18.75 \%$ siswa kurang setuju, dan $17.1 \%$ siswa sangat tidak setuju. Hasil tersebut menunjukkan bahwa siswa tertarik, senang, dan aktif dengan pembelajaran tematik, karena persentase terbanyak diperoleh pada alternative jawaban sangat setuju dan setuju. Hal ini sesuai dengan pendapat Akbar, Sa'dun dkk. (2016:19) yang menyatakan bahwa salah satu karakteristik pembelajaran tematik yang perlu dipahami, yaitu pembelajaran tematik menggunakan prinsip belajar sambil bermain dan menyenangkan melalui metode yang dapat mengaktifkan siswa dalam kegiatan pembelajaran.

Wawancara terhadap guru kelas I dan IV untuk mengetahui tanggapan guru tentang pelaksanaan pembelajaran tematik, diperoleh hasil bahwa pelaksanaan pembelajaran tematik pada awalnya dilaksanakan di kelas I dan IV pada tahun ajaran 2017/2018. Kemudian pelaksanaanya mulai berkembang pada kelas II dan V. Hal tersebut sesuai dengan Permendikbud nomor 67 tahun 2013 tentang Kerangka Dasar dan Struktur Kurikulum SD/MI yang menyebutkan bahwa pelaksanaan kurikulum 2013 pada SD/MI dilaksanakan melalui pembelajaran tematik terpadu dari kelas I sampai kelas VI. Pelaksanaan pembelajaran tematik di kelas I dan IV sudah berjalan lancar. Akan tetapi guru masih menemukan kendala pada saat menyampaikan materi, dimana siswa memiliki kemampuan kognitif yang bervariasi. Sehingga pembelajaran tidak dapat berjalan dengan maksimal karena harus menunggu siswa yang memiliki kemampuan kognitif rendah.

\section{SIMPULAN}

Berdasarkan hasil penelitian mengenai pelaksanaan pembelajaran tematik di SDN 7 Kebuemen pada kelas I dan IV dapat disimpulkan bahwa:

1. Pelaksanaan pembelajaran tematik sudah baik. Dengan persentase kegiatan awal $66.67 \%$, kegiatan inti $57.14 \%$, dan kegiatan akhir $75 \%$.

2. Tanggapan siswa terhadap pembelajaran tematik menunjukkan sikap positif. Dengan persentase sangat setuju $29.17 \%$ dan setuju $29.17 \%$.

3. Wawancara kepada guru kelas I dan IV memberikan hasil bahwa pembelajaran tematik sudah berjalan dengan lancar, akan tetapi guru masih menemukan kendala dalam hal kemampuan kognitif siswa yang bervariasi. Sehingga pembelajaran kurang maksimal karena harus menunggu siswa yang memiliki kemampuan kognitif rendah. 
Untuk ke depannya guru perlu memahami kemampuan kognitif siswa agar pembelajaran dapat berjalan secara maksimal. Untuk penelitian selanjutnya perlu dilakukan penelitian lebih mendalam terkait pelaksanaan pembelajaran tematik.

\section{DAFTAR PUSTAKA}

Akbar dkk. (2016). Implementasi Pembelajaran Tematik di Sekolah Dasar. Bandung: PT Remaja Rosdakarya.

Irwandi. (2012.) pelaksanaan Model Pembelajaran Tematik Bagi Siswa Tuna Grahita Ringan Di SLB Hikmah Revormasi Padang (Versi Elektronik). Jurnal IImiah Pendidikan Khusus, 1(2):192.

Janawi. (2012). Kompetensi Guru Citra Guru Profesional. Bandung: Alfabeta.

Kurniasih, I dan Berlin, S. (2016). Implementasi Kurikulum 2013 Konsep \& Penerapan. Surabaya: Kata Pena.

Mulyasa. (2015). Guru Dalam Implementasi Kurikulum 2013. Bandung: PT Remaja Rosdakarya

Sugiyono. (2017). Metode Penelitian Kuantitaif, Kualitatif, dan RnD. Bandung: Alfabeta. 